\title{
Is the COVID-19 regulation that prohibits parental visits to their children who are patients in hospital invalid in terms of the Constitution? What should hospitals do?
}

\author{
D J McQuoid-Mason, BComm, LLB, LLM, PhD \\ Centre for Socio-Legal Studies, University of KwaZulu-Natal, Durban, South Africa
}

Corresponding author: D J McQuoid-Mason (mcquoidm@ukzn.ac.za)

\begin{abstract}
This article deals with whether the COVID-19 regulation that prohibits parental visits to their children who are patients in hospital is invalid in terms of the Constitution of South Africa. The article contends that the ban on visits by parents to their children in hospital is a violation of the children's rights provisions of the Constitution regarding the 'best interests of the child', and the 'best interests standard' in the Children's Act 38 of 2005. The article also points out that the regulations are not saved by the limitations clause of the Constitution, because the restriction is not 'reasonable and justifiable' and a 'less restrictive means' can be used to achieve the same purpose of preventing the spread of the COVID-19 virus. The article concludes that the relevant regulation is legally invalid, and hospitals would be fully justified in allowing parental visits to child patients provided proper precautions are taken to contain the virus.
\end{abstract}

S Afr Med J 2020;110(11):1086-1087. https://doi.org/10.7196/SAMJ.2020.v110i11.15273

The question has arisen whether the COVID-19 regulation ${ }^{[1]}$ (regulation 40) that prohibits parental visits to their children who are patients in hospital is invalid in terms of the Constitution of South Africa. ${ }^{[2]}$ In order to answer this, it is necessary to consider: (i) the provisions of the COVID-19 regulation; (ii) the constitutional provisions regarding children's rights; (iii) whether the restrictions in the regulations, as they apply to parental visits to their children in hospital, are a 'reasonable and justifiable' limitation in terms of the Constitution; and (iv) what hospitals should do.

\section{Provisions of the COVID-19 regulations}

The level 3 COVID-19 regulations $^{[1]}$ in terms of the Disaster Management Act 57 of $2002^{[3]}$ were not amended during level 2 and provide, among other things, that:

'All visits by members of the public to ... health establishments and facilities, except to receive treatment or medication, subject to strict adherence to health protocols ... [a]re prohibited except to the extent and in the manner directed by the relevant Cabinet member' (regulation 40).

It seems that the relevant Minister has not decreed otherwise, and in terms of the regulations it appears prima facie that visits by parents to their children in hospital, including newborns, are not legally allowed.

However, it should be noted that this regulation was introduced as regulation 25 during level 4 restrictions $\mathrm{s}^{[4]}$ and re-enacted during level 3 restrictions as regulation $40,{ }^{[1]}$ and is not appropriate for level 2 . For instance, even under the level 3 restrictions, ${ }^{[1]}$ children could return to schools (regulation 5(3)), and in terms of the level 2 regulations, ${ }^{[5]}$ social gatherings of less than 10 people are allowed in private homes (regulation $55(\mathrm{k})$ ). The question of reconsidering hospital visits is apparently under discussion by the Ministerial Advisory Committee. It is submitted, however, that the deprival of parental visits to their children in hospitals, including maternity wards, is a clear violation of children's rights under the Constitution. ${ }^{[2]}$

\section{Constitutional rights of children}

The Constitution ${ }^{[2]}$ provides that children have the right 'to family care or parental care' (section 28(b)) and that a 'child's best interests are of paramount importance in every matter concerning the child' (section 28(2)). The Constitution does not define a 'child's best interests', but the Children's Act 38 of $2005^{[6]}$ sets out a 'best interests of the child standard. The standard states that the following factors should be taken into account, among other things: (i) the child's age, maturity and stage of development, gender, background, and any other relevant characteristics; (ii) the child's physical and emotional security and his or her intellectual, emotional, social and cultural development; (iii) any disability that the child may have; and (iv) any chronic illness from which the child may suffer (section 7(1)).

The prohibition against hospital visits by parents is a clear violation of the child's right to 'family care or parental care'. It is also likely to undermine the child's 'emotional security'. Furthermore, the other factors mentioned above in the standard are likely to either exacerbate or alleviate such emotional insecurity.

Are the restrictions in the regulations, as they apply to parental visits to their children in hospital, a 'reasonable and justifiable' limitation in terms of the Constitution?

The Constitution ${ }^{[2]}$ provides that a right may be limited 'in terms of law of general application to the extent that the limitation is reasonable and justifiable in an open and democratic society based on human dignity, equality and freedom' (section 36(1)). The Constitution states that when considering whether the limitation is reasonable and justifiable, the following factors must be taken into account: (i) the nature of the right; (ii) how important it is to limit 
the right; (iii) the nature of the limitation and its extent; (iv) the relationship between the limitation and its purpose; and $(v)$ whether there are less restrictive means to achieve the purpose (section 36(1) (a)-(e)).

In the case of visits to children in hospital by their parents, 'the nature of the right' is the right of such children to 'parental care', and to have their 'best interests' considered 'paramount'. While it is 'important to limit' the right by imposing strict conditions on how the visits take place in order to prevent the spread of the COVID-19 virus, this does not require a complete ban on such visits. The 'nature and extent of the limitation' is too broad - given that children are allowed to attend school under the level 3 restrictions ${ }^{[1]}$ (regulation $5(3)$ ), and that up to 10 people may attend social gatherings in residences under the level 2 lockdown regulations ${ }^{[5]}$ (regulation $55(\mathrm{k}))$. The 'relationship between the limitation and its purpose' is that the limitation is overbroad. Other measures may be taken to prevent the spread of the COVID-19 virus without having to ban parents from visiting their children. There are 'less restrictive means to achieve the same purpose', e.g. by restricting the visits to individual parents one at a time, providing parent visitors with personal protective equipment, and ensuring that they adhere to the other measures in place in the hospital to prevent the COVID-19 virus spreading.

It is therefore submitted that the ban on visits by parents to their children in hospital is not 'reasonable and justifiable' according to the limitations criteria in the Constitution ${ }^{[2]}$ (section 36(1)). Accordingly, the provisions in the COVID-19 regulations ${ }^{[1]}$ that seek to ban parental visits to their children in hospital, under appropriate safeguards against the spread of the virus, are legally invalid.

\section{What should hospitals do?}

Until the regulations are updated, it is submitted that hospitals will be fully justified in allowing parental visits to their children in hospital - provided strict precautions are taken to prevent the spread of COVID-19 infection. Although this is a violation of the COVID19 regulations ${ }^{[5]}$ prohibiting hospital visits other than for treatment or medication, such regulations are invalid to the extent that they ban parents from visiting their children in hospitals. This is because they violate the children's rights provisions of the Constitution. ${ }^{[2]}$ The Constitution is the supreme law of the country (section 2), and even in disaster situations, any limitations on a person's constitutional rights and freedoms must comply with the limitations clause in the Constitution (section 36).
In this instance, hospitals prosecuted for failing to observe the provisions of the COVID-19 regulation $\mathrm{s}^{[5]}$ by allowing parental visits to children - provided adequate safeguards are in place to prevent the spread of the virus - will have a valid defence. In any event, given that the regulation in question (regulation 40) was designed for the level 3 and 4 lockdowns, it is highly unlikely that hospitals will be prosecuted for allowing such visits under level 2 .

\section{Conclusions}

While it violates the COVID-19 regulations to allow parents to visit their children in hospital, it is submitted that this may be justified in terms of the Constitution on two grounds: $(i)$ it is in the 'best interests' of the children; and (ii) there are no 'reasonable and justifiable' grounds for limiting such visits - provided proper precautions are taken to contain the virus. The Constitution is the supreme law of the country, and COVID-19 regulations that violate the rights and freedoms in it must be shown to be 'reasonable and justifiable' under the limitations clause. In this instance, as has been demonstrated above, the relevant regulation fails the limitations test, and is therefore invalid in terms of parental visits to children in hospitals under strict conditions to prevent the spread of the COVID-19 virus.

\section{Declaration. None.}

Acknowledgements. None.

Author contributions. Sole author.

Funding. None.

Conflicts of interest. None.

1. South African Government. Disaster Management Act: Regulations: Alert level 3 during Coronavirus COVID-19 lockdown of 28 May 2020 as amended. https://www.gov.za/coronavirus/alert-level-3 (accessed 29 August 2020)

2. South African Government. Constitution of the Republic of South Africa, 1996. https://www.gov.za/ documents/constitution-republic-south-africa-1996 (accessed 29 August 2020).

3. South African Government. Disaster Management Act 57 of 2002. https://www.gov.za/documents/ South African Government. Disaster Management Act
disaster-management-act (accessed 29 August 2002).

4. South African Government. Disaster Management Act: Regulations: Alert level 4 during Coronavirus COVID-19 lockdown. Pretoria: Government Printer. https://www.gov.za/coronavirus/guidelines COVID-19 lockdown. Pretoria: Government Printer. https://www.gov.za/coronavirus/guidelines (accessed 8 September 2020).

5. South African Government. Disaster Management Act: Regulations: Alert level 2 during Coronavirus COVID-19 lockdown. https://www.gov.za/documents/disaster-management-act-regulations-alertlevel-2-during-coronavirus-covid-19-lockdown-17 (accessed 29 August 2020).

6. South African Government. Children's Act No. 38 of 2005. https://www.justice.gov.za/legislation/ acts/2005-038\%20childrensact.pdf (accessed 29 August 2020).

Accepted 8 September 2020. 